\title{
CROSS-LEVEL ANALYSIS: THE ROLE OF KNOWLEDGE MANAGEMENT MEDIATES THE EFFECT OF ORGANIZATIONAL CULTURE ON JOB PERFORMANCE
}

\author{
Fahmi Jahidah Islamy*, Tjutju Yuniarsih, Eeng Ahman, and Kusnendi \\ Universitas Pendidikan Indonesia
}

\begin{abstract}
This study aims to examine the influence of organizational culture on performance through knowledge management. The sample in this study amounted to 259 lecturers at private universities in the city of Bandung. Twolevel hierarchical linear modeling (HLM) is used to analyze hierarchical structure data in this study, namely at the lecturer level as an individual and at the study program as a group level. The results showed that organizational culture had a significant positive effect on knowledge management, knowledge management had a significant positive impact on performance, and organizational culture had a positive and significant impact on performance directly or indirectly.

Keywords: Organizational culture, Knowledge management, Job performance, Multilevel analysis, Linear model hierarchy (HLM)
\end{abstract}

Submitted: 30 May 2020; Revised: 7 June 2020; Accepted: 9 June 2020

*Corresponding author : fahmiislamy10@upi.edu

DOI: $10.24252 /$ minds.v7i1.13991

ISSN-E: 2597-6990

ISSN-P: 2442-4951 


\section{INTRODUCTION}

Knowledge management has emerged as a field of science that has received attention and support from several industry communities (Kebede, 2010; Rubenstein-montano, Liebowitz, Buchwalter, \& Mccaw, 2001). Knowledge management is very closely related to every activity in higher education. Higher education is an organization that almost all organizational activities are related to knowledge, knowledge creation, knowledge sharing, and knowledge utilization (Islamy, 2013). Therefore, knowledge management has an essential role in improving the performance of lecturers in supporting producing qualified students who can compete in the world of work. But the implementation of knowledge management in organizations, especially in universities, must pay attention to the culture or values adopted by all members of the high level, whether the existing culture has supported any knowledge management activities or not.

Organizational culture is a significant factor in the success of knowledge management in organizations (Alavi, Kayworth, \& Leidner, 2006; Allameh, Zamani, Mohammad, \& Davoodi, 2011; Islamy, 2013; Park, Ribiere, \& Schulte Jr, 2004). Organizational culture can not only affect knowledge management, but can also affect employee job performance (Shahzad, Superior, \& Lahore, 2013). A conducive culture will provide an opportunity for lecturers to improve their competencies and abilities that can enhance the work of the lecturer. Besides, some studies state that organizational culture has a significant influence on performance (Balthazard, Cooke, \& Potter, 2006; Martono, La, \& Mahrani, 2019; Shahzad et al., 2013; Xenikou \& Simosi, 2006).

There is a research gap regarding the influence of organizational culture variables on knowledge management. Research shows that if the organization implements a culture of control, it will negatively affect the knowledge management process (Chang \& Lin, 2015). There is also a research gap regarding the influence of organizational culture on employee performance that corporate culture has no significant effect on employee performance (Troena \& Setiawan, 2012).

This research is expected to be able to contribute to the development of theory for academics, especially in funding organizational culture, knowledge management, and job performance. The results of the study are expected to contribute to the enrichment of knowledge and insights about phenomena in the study of organizational behavior and human resource management. This study uses a multilevel analysis approach that is needed in the study of organizational behavior because, in essence, organizational behavior consists of individual expression and group behavior. The use of multilevel analysis in organizational behavior research is expected to be a reference for further investigation as a reference for multilevel analysis, which is still rarely done in research, especially in Indonesia. To solve the problems that have been described, this study focuses on testing individual behavior (lecturer) at level one, and group behavior (study 
program) at level two. The variable at level one is lecturer behavior in knowledge management and job performance, while at level two is organizational culture.

\section{THEORETICAL REVIEW}

\section{Organizational Culture and Knowledge Management}

Organizational culture refers to a system of shared meaning held by members of the organization that differentiates it from other organizations (Robbins \& Judge, 2013). Seven main characteristics of the essence of organizational culture according to (Robbins \& Judge, 2013): (1) innovation and risk-taking, (2) attention to detail, (3) outcome orientation, (4) people orientation, (5) team orientation, (6) aggressiveness, dan (7) stability. (Luthans, 2011) organizational culture has essential characteristics, namely: (1) Observed behavioral regularities, (2) Norms, (3) Dominant values, (4) Philosophy, (5) Rules, dan (6) Organizational climate. In research to measure organizational culture variables using the theory of (Denison \& Mishra, 1989) consisting of (1) Involvement: member in the organization has the commitment and experience have organizations, (2) Consistency: emergent behavior based on the core values of the organization. (3) Adaptability: organizations can adapt to change and able to translate strategies and targets with action and (4) Mission.

Based on the results of research conducted by (Alavi et al., 2006; Allameh et al., 2011; Islamy, 2013; Fahmi Jahidah Islamy \& Nurjaman, 2018; Park et al., 2004) organizational culture has a significant effect on knowledge management. Knowledge management is the knowledge that is built and then realized in an organization through activities, after which knowledge is spread and shared by all members of the organization so that new experience is seen as something economical to be used to replace old knowledge (Rowley, 1998).

There are three processes in knowledge management. They are (1) knowledge creation, through socialization stages, externalization of combinations, and internalization between individuals, organizations, and the environment. (2) Knowledge dissemination: information exchange, knowledge exchange in groups or organizations. Knowledge sharing is considered as a combination of sharing information, concepts, and experiences between members in the organization that can be horizontal or vertical. (3) Knowledge Application is to include orientation of the use of new knowledge for corporate decision making, making corporate strategies in increasing organizational effectiveness (Abdulraheem et al., 2017), thus:

H1: Organizational culture has a significant positive effect on knowledge management

\section{Knowledge Management and Job Performance}

An organization considers that improving performance does not only depend on tangible assets and organizational facilities it has, but also can utilize the knowledge that is in the minds of its employees (Abdulraheem et al., 2017). 
Studies indicate that knowledge management affects job performance (Martono et al., 2019; Masa'deh, Shannak, Maqableh, \& Tarhini, 2017; Sigala \& Chalkiti, 2015). Performance is mostly a key to an organization in achieving its goals because performance is usually used as an evaluation material for leaders or managers. Performance is individual because each member of the organization has mixed performance results. Performance depends on a combination of competencies and the opportunities provided by the organization. Mangkunegara (2017:67) states the term performance comes from the word job performance or actual performance, which is the result of the quality and quantity of work produced by employees in carrying out work per the responsibilities given.

Measurement of performance variables in this study is to use a reference from (Mathis \& Jackson, 2008), (1) quantity of work, (2) quality of work, (3) compatibility with others, (4) presence at work, (5) length of service, dan (6) flexibility. Improve performance can be done by holding informal meetings between management and employees to evaluate performance and how to improve it, prepare employees and train them, introduce them to evaluation criteria, and prepare them to meet the goals set in the performance plan (Abualoush, et al., 2017).

H2: Knowledge management has a significant positive effect on performance

\section{Organizational culture and performance}

Organizational culture is a mindset and underlying assumptions held by an individual in a particular group or organization with the intention that the organization can make decisions in overcoming the problems of the organization. The mindset and assumptions arise due to the adaptation and interaction of individuals with the organization, or individuals with other individuals in the organization so that they have the same thoughts and understanding so that a healthy organizational culture can improve employee performance (Balthazard et al., 2006; Martono et al., 2019; Shahzad et al., 2013; Xenikou \& Simosi, 2006). The concept of employee performance is a concept that has received much attention from researchers in the field of management, employee performance is seen as a result of employee behavior, from the effects of training and everything learned, and it is a product of the mental and psychological abilities of individuals (Abualoush et al., 2017).

H3: Organizational culture has a significant positive effect on performance

H4: Organizational culture has a significant positive effect indirectly on performance through Knowledge management as a mediating variable 


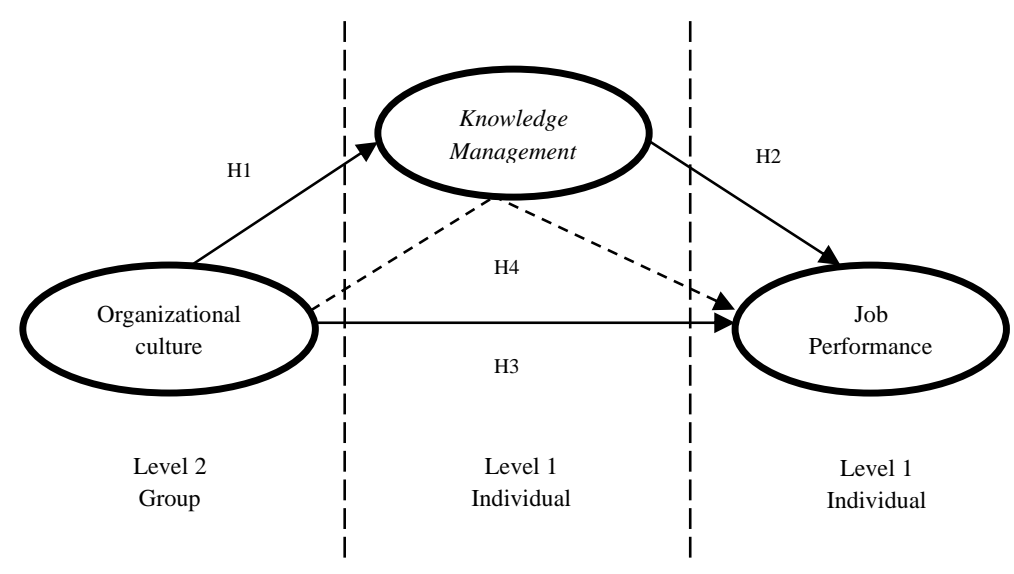

Figure 1. Conceptual Framework

\section{METHODOLOGY}

The design of this study uses a quantitative approach, with the type of analytical research. The study population was all lecturers at private universities in Bandung, obtained a sample of 259 lecturers with 50 groups (in the program). The type of data used in this study is primary data using printed questionnaires or online questionnaires regarding statements about the variables of this study, namely organizational culture, knowledge, and lecturer performance. Testing the validity of using the Confirmatory Factor Analysis method, using AMOS 22.0 Hypothesis testing in this study, uses hierarchical linear modeling (HLM) using HLM 8.0 software.

\section{RESULTS}

\section{Confirmatory Factor Analysis}

In testing the validity of using the CFA (Confirmatory Factor Analysis) method, statement items (indicators) are said to be valid if they have a factor loading value $>0.5$ (Hair, Black, Babin, \& Anderson, 2014). By observing Table 1 and Figure 2, the factor loading values for all indicators are $>0.5$. To verify the validity of each variable, a confirmatory factor analysis (CFA) was carried out. The CFA results show an adequate match ( $p<0,05$, AGFI 0.803, CFI 0.928, TLI 0.924, GFI 0.821 dan RMSEA 0,44). 


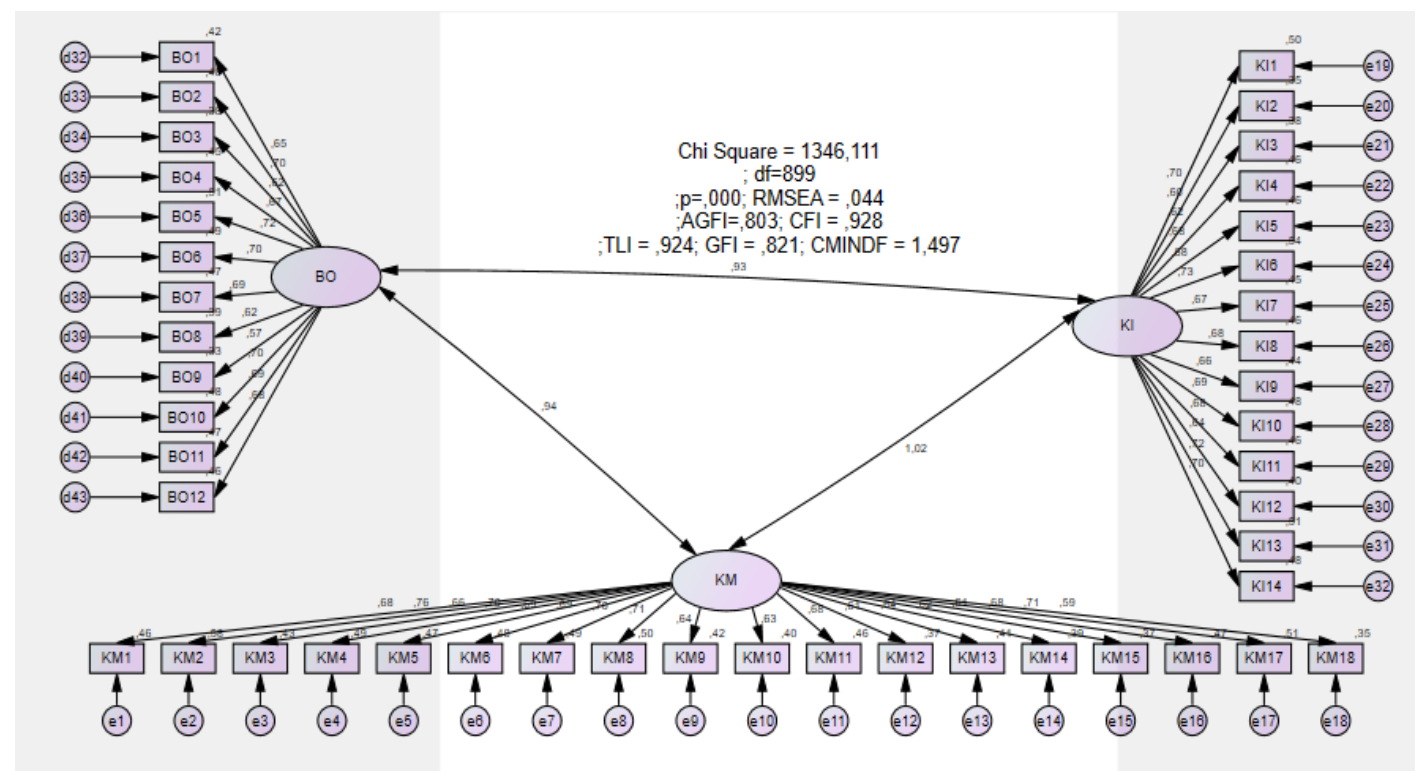

Figure 2. Estimation Results Confirmatory Factor Analysis Model inter Constructs

Table 1. Estimation Results Confirmatory Factor Analysis Model inter Constructs

\begin{tabular}{|c|c|c|c|c|c|}
\hline \multicolumn{2}{|c|}{ Budaya Organisasi } & \multicolumn{2}{|c|}{ Knowledge Management } & \multicolumn{2}{|c|}{ Kinerja } \\
\hline Indikator & $\begin{array}{l}\text { Factor } \\
\text { Loading }\end{array}$ & Indikator & $\begin{array}{c}\text { Factor } \\
\text { Loading }\end{array}$ & Indikator & $\begin{array}{c}\text { Factor } \\
\text { Loading }\end{array}$ \\
\hline BO12<--- BO & 676 & KM18<--- KM & ,592 & KI1 <--- KI & ,704 \\
\hline BO11 <--- BO & 686 & KM17<--- KM & 711 & KI2 <--- KI & ,596 \\
\hline BO10<--- BO & 696 & KM16<--- KM & 684 & KI3 <--- KI & 617 \\
\hline BO9 <--- BO & ,572 & KM15 <--- KM & 611 & KI4 <--- KI & 680 \\
\hline BO8<--- BO & ,624 & KM14 <--- KM & 621 & KI5 <--- KI & 681 \\
\hline BO7 <--- BO & 687 & KM13 <--- KM & 638 & KI6<--- KI & 733 \\
\hline BO6 <--- BO & 702 & KM12 <--- KM & 612 & KI7<--- KI & 668 \\
\hline BO5 <--- BO & 717 & KM11 <--- KM & 677 & KI8<--- KI & 676 \\
\hline BO4 <--- BO & 672 & KM10 <--- KM & 631 & KI9<--- KI & 662 \\
\hline BO3<--- BO & 616 & KM9 <--- KM & 644 & KI10<--- KI & 691 \\
\hline BO2 <--- BO & 696 & KM8 <--- KM & 706 & KI11 <--- KI & 677 \\
\hline BO1 <--- BO & 651 & KM7 <--- KM & 701 & KI12<--- KI & 635 \\
\hline & & KM6 <--- KM & 693 & KI13<--- KI & 716 \\
\hline & & KM5 <--- KM & 686 & KI14<--- KI & 696 \\
\hline & & KM4 <--- KM &, 698 & & \\
\hline & & KM3 <--- KM & 656 & & \\
\hline & & KM2 <--- KM & 759 & & \\
\hline & & KM1 <--- KM & 680 & & \\
\hline
\end{tabular}

Note: factor loading $>0.5$

Hypothesis Test Result

Before conducting a hypothesis test with HLM, it is necessary to do the ICC test (interclass correlation coefficient) ICC value must be greater than 0.1 . By using the software, HLM then obtained results of hypothesis testing as follows: 
Table 2. Testing Results Hypothesis 1

\begin{tabular}{lrrrrr}
\hline Fixed Effect & Coefficient & $\begin{array}{r}\text { Standard } \\
\text { error }\end{array}$ & t-ratio & $\begin{array}{r}\text { Approx. } \\
\text { d.f. }\end{array}$ & $p$-value \\
\hline For INTRCPT1, $\beta_{0}$ & & & & & \\
INTRCPT2, roo & 3.856971 & 0.019426 & 198.543 & 48 & $<0.001$ \\
BO_MEAN2, r 01 & 0.997837 & 0.055610 & 17.944 & 48 & $<0.001$ \\
\hline
\end{tabular}

Equation:

$$
\mathrm{KM} 1 \mathrm{ij}=\gamma 00+\gamma 01 * B O \_M E A N 2 j+u 0 j+r i j
$$

Based on Table 2, which explains the testing of hypothesis 1 using HLM, the result supported $\mathrm{H} 1$. Organizational culture has a positive and significant influence on the implementation of knowledge management of lecturers at private universities in Bandung $(\gamma=0.99, \rho=<0.001)$.

Table 3. Testing Results Hypothesis 2

\begin{tabular}{lcrrrr}
\hline Fixed Effect & Coefficient & $\begin{array}{r}\text { Standard } \\
\text { error }\end{array}$ & $t$-ratio & $\begin{array}{r}\text { Approx. } \\
\text { d.f. }\end{array}$ & $p$-value \\
\hline $\begin{array}{r}\text { For INTRCPT1, } \beta_{0} \\
\text { INTRCPT2, } \gamma_{00}\end{array}$ & 3.840871 & 0.011907 & 322.579 & 49 & $<0.001$ \\
$\begin{array}{r}\text { For KM1 slope, } \beta_{1} \\
\text { INTRCPT2, } \gamma_{10}\end{array}$ & 0.946254 & 0.018020 & 52.512 & 208 & $<0.001$ \\
\hline
\end{tabular}

Equation:

$$
K I 1 i j=\gamma 00+\gamma 10^{*} K M 1 i j+u 0 j+r i j
$$

Based on Table 3, which explains the testing of hypothesis 2 using HLM, the results are supported $\mathrm{H} 2$. Knowledge management has a positive and significant effect on the performance of lecturers at Bandung's private University $(\gamma=0.94, \rho=<0.001)$

Table 4. Testing Results Hypothesis 3

\begin{tabular}{lrrrrr}
\hline Fixed Effect & Coefficient & $\begin{array}{r}\text { Standard } \\
\text { error }\end{array}$ & $t$-ratio & $\begin{array}{r}\text { Approx. } \\
\text { d.f. }\end{array}$ & $p$-value \\
\hline For INTRCPT1, $\beta_{0}$ & & & & & \\
INTRCPT2, $\gamma_{00}$ & 3.843180 & 0.021269 & 180.697 & 48 & $<0.001$ \\
BO_MEAN2, $\gamma_{01}$ & 0.880618 & 0.066004 & 13.342 & 48 & $<0.001$ \\
\hline
\end{tabular}

Equation:

$$
K I 1 i j=r 00+r 01 * B O \_M E A N 2 j+u 0 j+r i j
$$


Based on Table 4 that explains hypothesis testing 3 using HLM, the result is supported H3. Organizational culture has a positive and significant influence on the performance of lecturers at private universities in Bandung $(\gamma=0.88, \rho=$ $<0.001)$

Table 5. Testing Results Hypothesis 4

\begin{tabular}{lrrrrr}
\hline Fixed Effect & Coefficient & $\begin{array}{r}\text { Standard } \\
\text { error }\end{array}$ & t-ratio & $\begin{array}{r}\text { Approx. } \\
\text { d.f. }\end{array}$ & $p$-value \\
\hline For INTRCPT1, $\beta_{0}$ & & & & & \\
INTRCPT2, $\gamma_{00}$ & 3.840653 & 0.011550 & 332.525 & 48 & $<0.001$ \\
BO_MEAN2, $\gamma_{01}$ & -0.083208 & 0.044065 & -1.888 & 48 & 0.065 \\
For KM1 slope, $\beta_{1}$ & & & & & \\
$\quad$ INTRCPT2, $\gamma_{10}$ & 0.965914 & 0.023088 & 41.835 & 208 & $<0.001$ \\
\hline
\end{tabular}

Equation:

$$
K I 1_{i j}=\gamma_{00}+\gamma_{01} * B O \_M E A N 2_{j}+\gamma_{10} * K M 1_{i j}+u_{0 j}+r_{i j}
$$

Based on Table 5, which explains the testing of hypothesis 4 using HLM, the result is supported H4. Organizational culture has a positive and significant impact on the performance of lecturers with knowledge management as a mediating variable $(\gamma=0.96, \rho=<0.001)$.

Based on the results of hypothesis testing, the regression value of the direct influence of organizational culture on lecturer performance has a smaller amount than the indirect effect by including knowledge management variables as mediators. So it can be said that if a university wants to improve the performance of lecturers with organizational culture as an independent variable, it must include the knowledge management variable as a mediating variable.

\section{DISCUSSION}

This section synthesizes empirical findings to answer the research questions of this study. Knowledge management becomes an essential strategy for organizations in sustainable competitive advantage (Chuang, 2004; Ndlela \& Toit, 2006). Organizational culture becomes an important and complicated issue in knowledge management (Allameh et al., 2011). The implementation of a corporate mission is one example of culture in organizations that can always support and be integrated with the knowledge management process. In higher education, institutions have an influential learning culture. Learning culture is one of the cultures that support knowledge management activities or processes (Francisco, 2014). Based on the results of the study showed that organizational culture has a positive and significant effect on knowledge management. This finding confirmed previous studies (Alavi et al., 2006; Allameh et al., 2011; Islamy, 2013; Fahmi Jahidah Islamy \& Nurjaman, 2018; Park et al., 2004). The organizational culture becomes an essential factor in supporting every activity of knowledge management, from the process of making knowledge, sharing knowledge to the stage of utilizing knowledge. Therefore, if an organization strives to enhance its 
innovative capabilities, it needs to focus on presenting an appropriate cultural environment and supporting an ongoing learning process. (Abdi et al., 2018)

The key to organizational success is changing human resources as initiators and agents of continuous change, forming processes and cultures that can enhance an organization's ability to change (Purnama, 2013). Sophisticated equipment owned by an organization will not be useful if the active role of human resources is not included. Job performance is defined as the total expected value for an organization derived from the behavior of an individual in doing work over a standard period (Dyne, 2013). Behavior, performance, and results are not the same. Behavior is what people do. Performance is the expectation of the organization to what people do. In contrast, results are the status or condition of people who are changed by contributing to an increase or decrease organizational effectiveness (Dyne, 2013).

In the psychology industry, the employee is a significant element of organizational performance (Abdulraheem et al., 2017). Job performance is the total value of the behavior produced by an individual in doing the work expected by the company within a predetermined period (Chiang \& Hsieh, 2012; Dyne, 2013). Also, individual employee performance is a key indicator that can be accepted and recognized in achieving organizational success (Masa'deh et al., 2017; Viswesvaran \& Ones, 2000; Zehir, Akyuz, \& Eren, 2013). The results showed that knowledge management positively and significantly affected the work of lecturers at private universities in the city of Bandung. The finding reinforces previous researches that reveal that knowledge management can affect individual performance in an organization (Martono et al., 2019; Masa' deh et al., 2017; Sigala \& Chalkiti, 2015).

Every individual in the organization has nature and has a different character with other individuals. Nature and style can be characterized so that it becomes an identity for the individual. If an individual or an employee has long worked in an organization, then nature and character can reflect the culture of the organization where the individual works. Organizational culture is the norm and shared values that guide the behavior of members in the organization (Balthazard et al., 2006; Cooke, Rousseau, \& Cooke, 1988; Luthans, 2011). An influential culture can lead to enthusiasm and motivation of employees in working so that organizational goals can be achieved (Shahzad et al., 2013).

To improve the performance of lecturers must be supported by the application of organizational culture that is compatible with the lecturer so that lecturers will voluntarily support and participate in the scope of higher education to provide their best abilities in achieving each goal set. Based on the results of the study indicate that organizational culture directly or indirectly has a significant positive effect on performance, as for previous studies, which suggested that corporate culture has a direct impact on performance, namely research (Balthazard et al., 2006; Martono et al., 2019; Shahzad et al., 2013; Xenikou \& Simosi, 2006). There are also previous studies conducted by (Martono et al., 2019) that examine the indirect effect of organizational culture on performance, with knowledge management as a mediator. 
A knowledge-based perspective is a function of the knowledge possessed by company resources to be combined, collected, and ultimately applied to provide a new view or opinion to be used to advance the company (Alavi et al., 2006). Knowledge management exists to be able to manage the knowledge that is in the minds of employees to be used by the company to produce innovation and new thoughts. The success of the organization in the 21st century by seeing competition increasingly fierce depends on the quality of the application of knowledge (Abdulraheem et al., 2017; Khalique, Isa, \& Shaari, 2011). The direct and indirect influence of organizational culture on lecturer performance shows that knowledge management as a mediator has the highest regression value compared to other hypotheses. It can be said that with knowledge, the application of useful knowledge management as an intermediary between organizational culture and performance can produce high lecturer performance. The view of knowledge management will always change. Knowledge management in every organization will be different, but the organization needs to develop and survive using knowledge (knowledge-based). Skilled knowledge management can bring significant benefits, including growth in labor productivity and improvement in service quality (Abdi et al., 2018). The potential use of knowledge management can be used effectively in business, especially in universities, to face competition in the future.

\section{FURTHER STUDY}

Like most studies, this research cannot be without limitations. First, future research designs might add one level to the multilevel analysis conducted, which is to add organizational levels. Thus it will involve data structures of three different levels, corporate level (e.g., organizational culture), group level (e.g., leadership), and individual level (e.g., performance). Secondly, this study was carried out only in one industry, namely education. Therefore, for further research, it is expected to examine the same variables but in different sectors. Third, as technological tools develop more and more that affect the way people interact, more research is needed to understand better human interactions with dynamic technology and their effects on people's cognitive and creative processes. How to use social media will be able to influence employee creativity. Finally, future research is expected to add variable company performance or company innovation as the influence of knowledge management and employee performance.

\section{REFERENCES}

Abdi, K., Mardani, A., Senin, A. A., Tupenaite, L., Naimaviciene, J., Kanapeckiene, L., \& Kutut, V. (2018). The Effect Of Knowledge Management, Organizational Culture And Organizational. 19(1), 1-19.

Abdulraheem, G., Alsheikh, A., Ali, E., Alnawafleh, T., Sobihah, M., Abd, B., ... Tambi, B. A. (2017). The Impact of Human Resource Management Practices, Organizational Culture, Motivation and Knowledge Management on Job Performance with Leadership Style as Moderating Variable in the Jordanian Commercial Banks Sector. 477-488. 
Abualoush, S. H., Obeidat, A. M., Tarhini, A., Masa'deh, R., \& Al-Badi, A. (2017). The role of Employees' Empowerment as an intermediary variable between Knowledge Management and Information Systems on Employees' Performance.

Alavi, M., Kayworth, T. R., \& Leidner, D. E. (2006). An Empirical Examination of the Influence of Organizational Culture on Knowledge Management Practices. 22(3), 191-224.

Allameh, M., Zamani, M., Mohammad, S., \& Davoodi, R. (2011). Procedia Computer The Relationship between Organizational Culture and Knowledge Management ( A Case Study: Isfahan University ). Procedia Computer Science, 3, 1224-1236. https://doi.org/10.1016/j.procs.2010.12.197

Balthazard, P. A., Cooke, R. A., \& Potter, R. E. (2006). Dysfunctional culture, dysfunctional organization Capturing the behavioral norms that form organizational culture and drive performance. https:// doi.org/10.1108/02683940610713253

Chang, C. L., \& Lin, T.-C. (2015). The role of organizational culture in the knowledge management process. Journal of Knowledge Management, 19(3), 433-455. https://doi.org/10.1108/JKM-08-2014-0353

Chiang, C., \& Hsieh, T. (2012). International Journal of Hospitality Management The impacts of perceived organizational support and psychological empowerment on job performance : The mediating effects of organizational citizenship behavior. International Journal of Hospitality Management, 31(1), 180-190. https://doi.org/10.1016/j.ijhm.2011.04.011

Chuang, S. (2004). A resource-based perspective on knowledge management capability and competitive advantage: an empirical investigation. 27, 459-465. https:/ / doi.org/10.1016/j.eswa.2004.05.008

Cooke, R. A., Rousseau, D. M., \& Cooke, R. A. (1988). Group E Organization Management. https:// doi.org/10.1177/105960118801300302

Dyne, V. (2013). Job Performance. 82-103.

Francisco, J. (2014). Journal of Work and Organizational Psychology.

Hair, J. F., Black, W. C. ., Babin, B. J., \& Anderson, R. E. (2014). Multivariate Data Analysis Seventh Edition (Seventh Ed). Pearson New International Edition.

Islamy, F. J. (2013). The Influence of Organizational Culture on the Implementation of Knowledge Sharing Lecturers at Bandung Indonesia University of Education. 1-13. Retrieved from https://www.emeraldinsight.com/doi/abs/10.1108/JKM11-2015-0427

Islamy, F. J., \& Nurjaman, R. (2018). Budaya Organisasi Dalam Mendukung Implementasi Knowledge Sharing Dosen Pada Perguruan Tinggi Negeri. 7(1), 2937.

Kebede, G. (2010). International Journal of Information Management Knowledge management: An information science perspective. International Journal of Information Management, 30(5), 416-424. https:/ / doi.org/10.1016/j.ijinfomgt.2010.02.004

Khalique, M., Isa, A. H., \& Shaari, J. A. N. S. (2011). Challenges for Pakistani SMEs in a Knowledge-Based Economy. 5(2), 74-80.

Luthans, F. (2011). Organizational behavior (12 th Edit). Paul Ducham. 
Mangkunegara. (2017). Manajemen Sumber Daya Manusia. Bandung: Rosda Martono, La, H., \& Mahrani, S. W. (2019). Peran Knowledge Manegement Sebagai Mediasi Pengaruh Budaya Organisasi Terhadap Kinerja Pegawai (The Effect of Knowledge Management on Performance of Employees That is Educated By Job Satisfaction). JUMBO (Jurnal Manajemen, Bisnis Dan Organisasi), 3(2), 64-78.

Masa'deh, R., Shannak, R., Maqableh, M., \& Tarhini, A. (2017). The impact of knowledge management on job performance in higher education: The case of the University of Jordan. Journal of Enterprise Information Management, 30(2), 244-262. https:/ / doi.org/10.1108/JEIM-09-2015-0087

Mathis, R. L., \& Jackson, J. H. (2008). Human Resource Management. United States of America: Thomson South-Westren.

Ndlela, L. T., \& Toit, A. S. A. (2006). Establishing a knowledge management programme for competitive advantage in an enterprise. 21(2001), 151-165.

Park, H., Ribiere, V., \& Schulte Jr, W. (2004). Critical attributes of organizational culture that promote knowledge management technology implementation success. 8(3), 106-117. https:/ / doi.org/10.1108/13673270410541079

Purnama, C. (2013). Influence Analysis of Organizational Culture Organizational Commitment Job and Satisfaction Organizational Citizenship Behavior ( OCB ) Toward Improved Organizational Performance. 3(5), 86-100.

Robbins, S. P., \& Judge, T. A. (2013). Organizational Behavior (Fifteenth). Pearson. Rowley, J. (1998). What is knowledge management? 416-419.

Rubenstein-montano, B., Liebowitz, J., Buchwalter, J., \& Mccaw, D. (2001). A systems thinking framework for knowledge management.

Shahzad, F., Superior, T., \& Lahore, C. (2013). Impact of Organizational Culture on Employees Job Performance: An Empirical Study of Software Houses in Pakistan. $5(2)$.

Sigala, M., \& Chalkiti, K. (2015). International Journal of Hospitality Management Knowledge management, social media and employee creativity. International Journal of Hospitality Management, 45, 44-58. https:// doi.org/10.1016/j.ijhm.2014.11.003

Troena, E. A., \& Setiawan, M. (2012). The Influence of Organizational Culture, Organizational Commitment to Job Satisfaction and Employee Performance ( Study at Municipal Waterworks of Jayapura, Papua Indonesia ) Jack Henry Syauta. 1(1), 69-76.

Viswesvaran, C., \& Ones, D. S. (2000). Perspectives on Models of Job Performance. $8(4), 216-226$.

Xenikou, A., \& Simosi, M. (2006). Organizational culture and transformational leadership as predictors of business unit performance. Journal of Managerial Psychology, Emerald Group, Vol. 21 No, 566-579.

Zehir, C., Akyuz, B., \& Eren, M. Ş. (2013). The Indirect Effects of Servant Leadership Behavior on Organizational Citizenship Behavior and Job Performance : Organizational Justice as a Mediator. Emerald Insight, 2(3), 113. 